\title{
International political system, supreme values and terrorism
}

\author{
Peter Bernholz
}

(C) Springer Science + Business Media B.V. 2006

\begin{abstract}
Terrorism is becoming a weapon of ever increasing importance to reach certain ends, given the potential of mass destruction available to leading international powers and the rise of one superpower dominating the international system. In most cases terrorism is driven by an ideology comprising a world view with supreme values. Since these values are absolutely true to believers, they have to be preferred to everything, so that terrorists are required to sacrifice not only the lives of others but also their own. It is therefore difficult to prevent this kind of terrorism. But the threatening damages can be mitigated by economic, technological and political decentralization. In the long run, it is even more important to win the spiritual fight. This can be done by starting from the fact that believers in ideologies whose supreme values are conflicting, can only live together peacefully, if they accept that each individual has the right to choose his or her own belief. A corresponding education has to prevent fundamentalist instruction and to inculcate the basic rules of a free society.
\end{abstract}

Keywords Terrorism $\cdot$ Supreme values $\cdot$ Fundamentalism $\cdot$ Crises $\cdot$ Islamist terrorism

\section{Introduction}

Terrorism is an old phenomenon, and all of its traits can be found in earlier times. Terrorism has already been systematically applied by the assassins, an Ismaelite Shiite sect for nearly two hundred years during the Middle Ages. Its members killed several leading personalities of the Seljuk Sultanate, including the famous Grand Vizier Nizam ul Mulk, and also directed their activities against the Christian Crusaders. The assassins were prepared to sacrifice their own lives for the supreme values to which they adhered, were centrally directed and had occupied several strongholds in Iran, Syria and Lebanon (for an excellent description of this and other sects, their religious motivation and methods see Rapoport, 1984). It follows that we agree with Rapoport, who rightly rejects the view that terrorism is a modern phenomenon

P. Bernholz

Center of Economics and Business, WWZ, Universitaet Basel, Postfach 142, CH-4003 Basel,

Switzerland

e-mail: Peter.Bernholz@unibas.ch 
caused by the developments of technology, "since weapons are cheaper, more destructive, easier to obtain and to conceal." (ibid., p. 658 f.). He realizes that

"Since doctrine, rather than technology, is the ultimate source of terror, the analysis of modern forms must begin with the French, rather than the Industrial Revolution." (ibid., p. 672).

But in spite of the long history of terrorism and of the fact that recent terrorism contains several ingredients already present in earlier historical periods, some of its preconditions have changed during the last decades, which seem to favor an increased terrorist activity or to alter its coloration. In the present paper we will first discuss these changes and then turn to the supreme values of terrorist movements which characterize again many present terrorist activities, which were also characteristic for the murders committed by the assassins.

\section{Changes in the international environment}

In our view there have been two important developments in recent decades which are bound to increase the probability of terrorism: First, technological innovations in the instruments of warfare, and second, changes which occurred in the international political system. The development of nuclear weapons and of intercontinental missiles makes it impossible for rational leaders of countries owning them to employ them against each other. This is also often true for their application against states not possessing such weapons. For they may be supported by other essential actors such that the risk of an escalation into an atomic war is too high. As I pointed out twenty years ago (Bernholz, 1985, p. 201):

“...because of this stalemate wars against non-essential states, possibly not with an actors own troops but with those of a satellite, guerilla wars, ideological and economic warfare, terrorism and revolution will be more and more prominently employed by members of the new balance of power system" [the rise of which I then envisaged and even now envisage as a future possible development].

Because of the superiority in modern arms, even excluding atomic weapons, of leading industrialized countries, it is also true that other states, and even more so organized non-state actors have no other possibility than to turn to revolution, guerilla warfare and terrorism to promote their aims or to seek relief for their grievances in the face of superior powers. In doing so, weaker states have to camouflage such activities, and non-state actors have to hide in the general population or in inaccessible areas to preserve their striking capabilities. On the other hand, modern technological developments have provided such states and organizations with several kinds of cheap arms capable to work terrible local destruction. Moreover, highly developed countries are rather vulnerable against terrorist acts. Networks of electricity or water supply, of transportation and communication can be badly hurt if they are centrally organized, that is if they are connected in central knots. Any strong centralization of activities offers a valuable target. And the development of modern means of communication provides the organizers of such acts not only with a broad echo through the mass media, but also with an easy way to coordinate their actions.

The changed conditions for terrorism because of the superiority of leading countries in modern arms has been early recognized by terrorists:

"The old method of guerilla warfare, as carried out from the hills and countryside, would be ineffective in a powerful country like the USA ... The new concept [of revolution] is Springer 
to huddle as close to the enemy as possible to neutralize his modern and fierce weapons.

The new concept creates conditions that involve the total community, whether they want to be involved or not..." (American black militant Robert Williams, February 1964 issue of his publication The Crusader, quoted from Sobel, 1975, p. 4).

Next, let us consider the changes in the international political system furthering terrorist activities. Before the two world wars, an international Balance of Power System comprising seven great powers existed. This ended with World War II, which led to a Bipolar System containing the USA and the Soviet Union. Finally, the Soviet Union broke down around 1990 because of the inferiority of its economic system and its closed state-dominated society, so that the USA remained as the only super-power.

But why did these events change the direction and the kind of terrorism? First, in a system of several great powers the grievances perceived by smaller states or by specific groups and organizations are usually referring to one or the other of these powers. Even if the groups and organizations direct their complaints against their own or neighboring countries not belonging to the great powers, they often see a relationship of them to the latter, and believe that their own governments are dominated by or are just puppets of them. But since there exist several essential actors, the repugnance, hate and ill-feelings are not concentrated on just one of them.

This changed already with the development of the bipolar system. Here the temptation is great to identify with the ideologies of one of them, and to direct the hateful actions against the other. It is thus not surprising that many governments, like Nasser's in Egypt, and organizations accepted and adopted the communist or socialist ideology of the Soviet Union, or followed a path more related to the USA. Consequently it was true until the 1970s that

"Although terrorists are found among adherents of almost every brand of left-wing or right-wing ideology, the overwhelming majority of today's terrorists can be described as leftist. Most have a New Left or Trotskyist character.” (Sobel, 1975, p. 6)

This changed at least with the breakdown of the Soviet Bloc. The communist ideology has lost much of its attractiveness because of its failure. This provided a chance for other ideologies to become influential in states supporting terrorist groups or in organizations willing to use terrorism. As stated by Hoffman (1998, p. 90 f.):

“... while the re-emergence of modern religious terrorism was initially closely associated with the Islamic revolution in Iran, within a decade of that event none of the world's major religions could claim to be immune to the same volatile mixture of faith, fanaticism and violence....

Significantly, during the 1990s the growth in the number of religious terrorist groups as a proportion of all active international terrorist organizations has not only continued but increased appreciably. In 1994, for example, a third (sixteen) of the forty-nine identifiable international terrorist groups active that year could be classified as religious in character and/ or motivation; and in 1995, the most recent year for which complete statistics are available, their number grew yet again, to account for nearly half (twentysix, or 46 per cent) of the fifty-six known, active international groups."

Moreover, with only the USA remaining as a superpower with an average per capita income far above that of most other countries, it is not surprising that most of the grievances of the elites of many countries and of many organizations are now directed against this country and its supporters. 


\section{Ideologies with supreme values as background and motivation of terrorism}

\subsection{Supreme value ideologies as a cause of terrorism}

We have already reported Rapoports thesis that doctrine is the ultimate source of terror, and have also referred to ideologies like communism, nazism and several religions ${ }^{1}$ with their supreme values as an important background of terrorist activities. But what is meant by these statements?

By a Supreme Value we understand an aim or a bundle of aims preferred to all other aims. If we want to express this idea with the help of a preference function, we could say that the aims of the Supreme Value are lexicographically preferred (for a discussion of lexicographic preference functions see Fishburn, 1974) to all others. Resources are only spent on these other aims if they are not needed to accomplish the goals of the Supreme Value. Put in other words, everything and everybody has to be sacrificed if this is necessary to reach them. Supreme values are typically ingredients of an ideology comprising a Weltanschauung, a comprehensive world view, which purports to be absolutely true. All people able to become believers have to be converted, be they for instance Aryans in the case of National Socialist, or proletarians in the Communist, or the whole of humanity in Christian or Muslim ideologies. According to certain ideologies some people, however, cannot be converted, for instance Jews according to Nazi and capitalists and bourgeois according to Communist ideology. Such groups are perceived to be enemies of the true creed, and have therefore either to work as subjects of the believers to reach the ideological ends, to be forced into emigration or to be eliminated. The same is true for potential believers who stubbornly resist the efforts of the true believers to win them as converts.

An ideology with supreme values is usually invented or revived by charismatic individuals able to win a broad following. Their creed is often contained in holy scriptures whose absolute truth cannot be doubted, but interpreted by a selected leadership. Since such ideologies want to convert all eligible people they are striving to take over existing nations to combine secular and spiritual power for the purpose to convert as many people as possible either by persuasion or by force. Force is also needed to break the resistance of opponents and to subjugate nonconvertibles. But to gain governmental power in a state, the ideological movement needs an effective organizational structure with a leader or leadership having the monopoly of interpreting the creed.

To be successful in this endeavor a crisis has usually to be present such that the ingredients of the ideology offer a solution to the problems perceived by the population. If the effort to gain secular power has been successful a totalitarian regime will develop if domestic opponents and non-convertibles have to be suppressed and if the supreme values demand that the creed is spread to the peoples of other countries or even of the whole globe, and this, if necessary, by force (see Bernholz, 1997, 2001 for a full exposition).

But what happens, if the ideological movement or organization has not yet been able to grasp secular power, or if it has lost it, for instance by war like the Taliban in Afghanistan, the Khmer Rouge in Cambodia and a branch of the Anabaptists after their Muenster kingdom had been routed. (Stayer, 1976, chapters 12 and 13). Then the probability is great that the movement turns to guerilla warfare and terrorism to finally gain or regain secular power against the forces of evil depicted as such by its ideology.

\footnotetext{
${ }^{1}$ Here we are only discussing certain fundamentalist interpretations of religions as a cause of terrorist activities. This does not mean that we deny the metaphysical truths revealed by religions. 
Terrorism based on ideologies with supreme values usually leads into fundamental conflicts. The true believer is fighting not just some other human beings, but the embodied forces of evil who are perceived as wanting to resist or even to obliterate the true creed and its beneficial consequences. He sees himself as an idealist fighting for the highest values, which are absolutely true. A true believer tries to prevent the victory of the forces of evil, to overcome them, and to establish the supreme values of his ideology. Also, the world view of the ideology depicts an image of the outside world that may be strongly at odds with a scientific perception and also with the understanding of common people who are not believers. And different ideologies may all have distorted views of each other, a fact which embitters their conflicts. More often than not, the distorted world views of ideological movements may also lead to an exaggerated vision of their capabilities to overcome the forces of organized states. This increases willingness to use terrorism, and leads to tough resistance by true believers before they can be defeated.

\subsection{Under which conditions do supreme value ideologies use terrorism?}

It has been stressed that ideologies containing supreme values are usually a dominant cause of terrorist acts. But does this mean that all ideologies with supreme values revert to terrorism? This question has certainly to be answered in the negative. Jews and Christians, Muslims, Jews and Christians, Hindus, Muslims and Sikhs, and also different Christian denominations and sects have often peacefully lived together in several countries for extended periods. What then are the reasons that ideologies with supreme values turn to terrorism, especially when they have been peaceful before? Or, why are some ideological movements peaceful or why do they become peaceful after waging wars or terrorism against non-believers? These are questions which are difficult to answer, but to which we will try to give at least some provisional answers.

Let us first state that most but not all ideologies imply that their supreme values contain absolute truths. As a consequence anybody not believing in them is at least wrong, if not a wrong-doer or sinner. This fact alone may explain that about all ideologies are in danger to be turned by adequate interpretations into belief systems requiring the conversion, persecution or even obliteration of those denying these absolute truths. On the other hand, not all ideologies contain supreme values requiring believers to convert, if necessary by pressure or force, all eligible people all over the globe or to subjugate the earth.

The Puritans moving to Massachusetts certainly cared deeply for the purity of their Protestant creed, and did not allow settlers of an even somewhat different protestant belief to stay in their dominion. But they felt no obligation to convert all other people outside Massachusetts to their convictions (Morgan, 1958). Whether his was a consequence of the fact that their power was too weak to try this is, however, an open question.

This leads us to a second reason, why even ideologies containing supreme values asking for global expansion may become peaceful and limit their objectives. If we look at the development of Christianity it is obvious that Christians became rather oppressive from the very time they began to dominate the Roman Empire after Emperor Constantine. Pagans and heretics were suppressed, temples destroyed or turned into churches etc. Crusades were undertaken against Muslims and Jews in the Near East, against the sect of the Cathars in what is now Southern France and against the pagan Prussians.

With the reformation persecutions and wars arose among the different Christian denominations culminating in St. Barthemelew's Night in France and the Thirty Years War in Central Europe. It seems that only the fact that none of the different religious ideologies was able 
to suppress the others, together with economic interests of princes finally brought about toleration in Europe (Bernholz, 1995).

Other examples are the revisions of communist ideology in the former Soviet Union and in China after it became clear that their forces were not sufficient to subjugate the world to their creed and to their system. It began with Stalin's "Communism in One Country" as a provisional postponement of the ultimate aim of communism, and ended with the reforms initiated by Deng and Gorbatchew. The latter required a wholesale reinterpretation of communism and an abolishment of its aim of global expansion as an ingredient of its ideology.

But what are the conditions that an ideology with expansionary supreme values may arise or is revived which can turn to terrorism if no other means seem to be available to reach its aims? We have already mentioned that the creation or revival of such a Weltanschauung is usually dependent on the appearance of a charismatic and creative personality. This seems to be an event which seems to be largely determined by chance.

The appearance of a Hitler, a Marx, an Engels, a Lenin or of the founders of Christian orders or of protestant reformers like St. Benedict, St. Francis of Assisi, St. Dominic (founder of the Dominican Order instrumental in the introduction of the Inquisition), Loyola (founder of the Jesuit Order), Luther, Zwingli (who died in a battle against Catholic Swiss Cantons) and Calvin (who created a totalitarian regime in Geneva) cannot be predicted. The same is true for Ibn Wahhab (on whose fundamentalist teachings the rule of the Saudi family in Saudi-Arabia is based) in the 18th century, Sayyid Qutb and Ibn Mawdudi (see below) in the 20th century like for other Muslim fundamentalist reformers.

But for ideological movements to find a mass following, crises seem to be necessary. The Marxist communist creed had to wait for decades until it succeeded to win secular power during the crisis in Russia during World War I, and similarly in China during and after World War II. The Nazis were only able to succeed in Germany because of the Great Depression. Note that both ideological movements applied terrorism to secure the domination of the respective states.

But when do ideological movements with expansionary aims turn to use terrorism? We have already pointed out that this is the case either when they want to gain secular power, or to regain it after they have lost it. Presently the military and economic dominance of leading developed countries, especially of the USA, necessarily reinforces the tendency to use terrorism because of the impossibility to succeed in open warfare against them.

\subsection{Examples of terrorist acts committed in the name of supreme values}

The use of terror by ideological movements oriented by supreme values is not a new phenomenon. The assassins have already been mentioned. Another example are the Thugs, an Indian sect sacrificing human beings to the goddess Kali, who were finally suppressed by the British in India in the first half of the 19th century. The Jewish Zealots and Sicarii may also be mentioned. They played leading roles in the insurrection against the Romans which ended with the Roman occupation of Jerusalem and the fall of Masada after the defenders had committed suicide (see Rapoport, 1984).

More recent examples are the terrorist acts of the Red Army Fraction in Germany and the Red Brigades in Italy, and the sarin nerve gas attack of the Aum Sect in the Tokyo subway system in 1994. The Aum sect was founded in 1988 and combines Buddhist and Hindu beliefs (Hubback, 1997, 19 f.). Presently, Maoists are fighting the government in Nepal, Islamic fundamentalists oppose the governments of Algiers and Egypt. Islamic terror is being used against Jews in Israel, against Christians in Pakistan, the southern Philippines and in different parts of Indonesia, and by Hindus against Muslims in Northwestern India. 
Islamic terror has been used against the United States and other countries on a number of occasions, culminating in the events of September 11, 2001, and more recently in Madrid (2004) and London (2005), not to mention the attacks on tourist centers like in Bali (2002) and Sharm el Sheikh (2005).

\section{Islamic supreme value systems as a basis for terror}

Like Christianity Islam has seen several revivals of fundamentalism during history, in which its supreme values were reinterpreted as demanding a holy war against pagans, and even the Jewish and Christian book religions. Christian fundamentalist revivals led during centuries to the persecution of pagans after the Roman emperors had been converted, to the crusades, to the persecution of the Cathars, to the totalitarian regime of Calvin in Geneva, and to the bloody religious wars among different Christian denominations, as between Catholics and Huguenots in 16th century France, or the Thirty Years War between Catholics and Protestants.

Today, however, though there still exist several fundamentalist Christian sects, the main danger of terrorism originates from Islamic fundamentalism (for a comprehensive discussion from a similar perspective see Aristegui, 2004). Let us, therefore, look at the ideological basis as presented by some important Muslim thinkers, and begin with a statement by the famous scholar Ibn Khaldûn, who lived around 1400:

"In the Muslim community, the holy war is a religious duty, because of the universalism of the (Muslim) mission and (the obligation to) convert everybody to Islam either by persuasion or by force. Therefore, caliphate and royal authority are united in (Islam), so that the person in charge can devote the available strength to both of them at the same time." (Ibn Khaldûn, vol. 1, p. 473, 1967).

This interpretation has been sharpened by other scholars. We first quote Ibn Tamiyya, who lived from 1263-1328, when the mongols under Timur attacked Damascus:

"The command to participate in jihad and the mention of its merits occur innumerable times in the Koran and the Sunna. Therefore it is the best voluntary [religious] act that man can perform ... Jihad implies all kinds of worship.... Since lawful warfare is essentially jihad and since its aim is that the religion is God's entirely and God's word is uppermost, therefore according to all Muslims, those who stand in the way of this aim must be fought." (Quoted in Peters, 1996, pp. 47-49)

The Indian Islamist Mawdudi (1903-1979) presented the following interpretation:

"Islam ... wants and requires the entire inhabited world. It does not want this in order that one nation dominates the earth and monopolizes its sources of wealth, .... No, Islam wants and requires the earth in order that the human race altogether can enjoy the concept and practical program of human happiness, by means of which God has honoured Islam and put it above the other religions and laws. In order to realize this lofty desire, Islam wants to employ all forces and means that can be employed for bringing about a universal all- embracing revolution. ... This far-reaching struggle that continuously exhausts all forces and this employment of all possible means are called jihad." (Quoted by Peters, 1996, p. 128.)

Let us finally quote Sayyid Qutb, 1906-1966, an Egyptian and chief ideologue of the Muslim Brotherhood, who was tortured and executed by Nasser's regime: 
"If we look at the sources and foundations of modern ways of living, it becomes clear that the whole world is steeped in Jahiliyya (pagan ignorance of divine guidance), and all the marvellous material comforts and high-level inventions do not diminish this ignorance. This Jahiliyya is based on rebellion against God's sovereignty on earth: It transfers to man one of the greatest attributes of God, namely sovereignty, and makes some men lords over others. It ... takes the form of claiming that the right to create values, to legislate rules of collective behavior, and to choose any way of life rests with men, without regard to what God has prescribed. ... The Islamic civilization can take various forms ..., but the principles and values on which it is based are eternal ... the worship of God alone, ... the supremacy of the humanity of man over material things, ... and the control of animalistic desires, respect for the family, the assumption of the vice-regency of God on earth according to His guidance and instruction, ... the rule of God's law [al-Shari'a] ...

\section{Political and economic consequences of terrorism based on the aims implied by supreme values}

It follows from the above that the presence of ideologies with supreme values is exacerbating the dangers of terrorism (for a formal model of Supreme Values and Terrorism see Bernholz, 2004):

1. True believers are prepared to sacrifice not only the lives of others but also their own life in following the demands of their creed. This makes it very difficult to protect targeted objects or persons against their attacks.

2. Believers are idealists experiencing no bad conscience in committing terrorist acts. This makes them more determined to execute their leaders or their own designs.

3. They are sure that their good cause will eventually win since the supreme values of the ideology are superior to anything else and absolutely true.

4. Believers are convinced that supposedly 'innocent victims' are in fact pagans or heretics from the perspective of their ideology. As a consequence they feel no qualms in killing or executing them.

5. The core of the true believers, the intellectual leaders come mostly from middle class or wealthy families. ${ }^{2}$ They studied, know the ways of their opponents and the economic and technical means to prepare efficiently their terrorist acts. It is therefore not poverty which breeds ideologies, their inventors and innovators, and their leading personalities, though a crisis stemming from increasing poverty may attract a mass following for the ideology.

6. The way of living of non-believers often contradicts the demands of Islam. The materialism in Western countries, the taking of interest, the immoral behavior of women and the acknowledgement of homosexual practices are abhorrent to Muslims.

And now the Christian USA with its superior economic and military strength, its domination of the mass media, and its support for the Jewish state is even invading or corrupting together with its allies the core countries of Islam. Moreover, the governments of these countries are often perceived by believers to be dominated by heretics. For though many rulers may follow the five most important commands of Allah, they have introduced secular law

\footnotetext{
${ }^{2}$ Compare the empirical study by Kruger and Maleckova (2003).

Springer
} 
and are not following the commands of the shariah. Therefore, true believers have the right and the duty to fight the Western infidels, but also their own degenerate governments.

But the tasks to be accomplished are huge, for not only heretic domestic governments have to be overthrown. For besides that the Western powers have to be weakened, their economies to be damaged, their governments shown as unable to protect their citizens, all this with the aim to turn them into believers. Consequently decisive terrorist acts are required which are mainly directed against leading opponents, against important symbols of the enemy and against the very centers of their political, military and economic strength. Especially attacks which are highly visible and covered by the mass media are attractive.

\section{Measures to protect against supreme value terrorism}

The technological developments leading to modern arms cannot be undone. Similarly, the USA will remain the only superpower for years or even decades, before new Great Powers like China and perhaps Europe, Russia and Brazil emerge as essential actors. It follows that the grievances felt by many people will be concentrated on the USA for a long time to come. The political consequences to be drawn because of this fact are two. First, the USA should mitigate these ill-feelings by a more cautious and moderate policy against foreign countries, organizations and citizens, which is instructed by a better understanding of their plights. Second, it should try to reach a much broader collaboration in its undertakings with the UN and as many allies as possible. Still, even such policies can only lead to a reduction of the ill-feelings against the USA as the superpower, but not to their removal.

It has been shown above that it is difficult to prevent supreme value terrorism since it is a 'holy' duty of true believers fighting in good faith the 'devilish' forces of darkness to spare nothing and nobody, even their own lives for the good case. But this does not mean that the political and economic damages cannot be reduced.

First, the danger does, as a rule, not so much arise from the military and political potential of states dominated by an ideological movement. For since its leaders and adherents have to follow the prescriptions of their ideology, which are usually at odds with a favorable economic development and the freedom of a pluralistic system, such countries cannot keep up with highly developed nations, but remain inferior to their economic and military capabilities.

This implies that the greatest danger for Western and 'Westernized' countries does arise from immigrant believers and especially the promoters of fundamental ideologies among them. Only true believers who have the chance to study, to inform themselves about the Western ways of living, and to acquire the necessary technical expertise, are able to commit the most conspicuous terrorist acts in such nations. It follows that much can be done by limiting the influx of strong believers, in preventing them to make proselytes under the mantel of religious or other tolerance. An early screening of the respective movements and their adherents can help much to limit the possibility of terrorist acts.

Second, the attention and the reports of mass media about the successful acts of terrorists are not only spreading the news of their success, but also contribute to their fame and attract new believers as potential imitators. It should thus be examined whether the sensational reporting of the mass media could not be restricted, of course a delicate task in a free society. Also, since attacks on leading political and economic persons are rather probable, reporting about their whereabouts and travels should be strictly limited.

Third, the centralization of technical and economic facilities is bound to attract highly devastating attacks. If the financial and other activities had not been concentrated in the two towers of the World Trade Center and instead been decentralized in the suburbs of New 
York, which could have been the case given modern computers and information networks, the damage would have been much smaller. From this perspective an idea like that of the Swiss Railway Authorities to concentrate their switching system in one location, seems to be a bad one. Decentralization is therefore an adequate recipe. Even a strongly federal political system is less vulnerable than a highly centralized one (Frey \& Luechinger, 2004).

\section{The spiritual battle}

To definitely remove the threat stemming from supreme value movements, the fight about spiritual values has to be won. Presently, the West has scarcely become aware of this fight and is even immobilized by its dogma of a 'multicultural society'. Indeed, its position in this dispute seems to be weak, because secularization has left the West with no substantive supreme values which could be opposed especially to those based on absolute truths revealed by God. For the adherence to Christian believes is waning. Moreover, it is not obvious how a confrontation of several belief systems with conflicting substantive supreme values which are thought to be absolutely true by the adherents of both creeds could be resolved by arguments and discussion.

If it is believed that the Quran is the definitive word of God, then it is difficult to contradict the results deduced by thinkers like Sayyid Qutb, for in this case there can only be a discussion about interpretations. Also, the argument can then no longer be accepted that everybody should have the right to take his or her own decisions. For these decisions might be violating the commands of God.

As a consequence, another approach has to be taken, which has to be based on the fact that different movements or groups of people may believe in different ideologies (including religions) with conflicting supreme values and that this will lead to hatred and violence if they try to convert people by pressure, threats or force. The only way to prevent this is to require all such movements to agree that no pressure or force, but only peaceful missionary work is permitted to convert others. But this implies, if the commandments of the different supreme values conflict, that secular law has to be established and to be acknowledged. It also means that the respective laws have to be promulgated by a legislature, executed by an administration and monitored by a judicial system not based on one of the supreme value systems. But this implies, moreover, that the legislature and the government have to be elected by all citizens, so that no one is excluded because of his or her creed. Moreover, minorities and the right of everybody have to be protected to select his or her own creed or convictions.

A free society implies the formal supreme value that everybody has the right to take his or her own decisions as long as the rights of others are not violated. This is the only way violent conflicts can be prevented, except by separating the world into different territories each dominated by only one ideology. But the latter alternative does not work if some supreme values demand a universal mission. The right to take one's own decision includes the right to sin, where the concept of 'sin' is interpreted differently by different creeds. But even monotheistic religions do admit that God created man with the faculty to sin.

The ideas just sketched also have a bearing for the education of school children. Religious instruction has to be allowed, but not by fundamentalist teachers asking for the conversion or suppression of others by force. Education has also the important task to teach the basic requirements and rules of a free and peaceful society. Each new generation has to learn how ideologies, religions, democracy and the constitution can be integrated to maintain a peaceful free society. 


\section{References}

Aristegui, G. de. (2004). El islamismo contra el islam. Les claves para entender el terrorismo yihadista. Ediciones B:S.A., Barcelona, Madrid, Mexico, Montevideo.

Bernholz, P. (1985). The international game of power. Berlin and New York: Mouton Publishers.

Bernholz, P. (1995). Supreme values, tolerance and the constitution of liberty. In: G. Radnitzky, \& H. Bouillon (Eds.), Values and the social order (Vol., 1, pp. 235-250). Values and society. Aldershot, Brookfield, USA and Hong Kong: Avebury.

Bernholz, P. (1997). Ideology, sects, state and totalitarianism: a general theory. Forum für osteuropäische Ideen- und Zeitgeschichte (Vol. 1 (1), pp. 51-84). Also In: H. Maier, \& M. Schaefer (Eds.), Totalitarismus und politische Religionen. Konzepte des Diktaturvergleichs, (Vol. II, pp. 271-298). Ferdinand Schöningh, Paderborn, München, Wien, Zürich.

Bernholz, P. (2001). Ideocracy and totalitarianism. A formal analysis incorporating ideology. Public Choice, $108,33-75$.

Bernholz, P. (2004). Supreme values as the basis for terror. European Journal of Political Economy, 20, $317-333$.

Fishburn, P.C. (1974). Lexicographic orders, utilities and decision rules: a survey. Management Science, 20, 1442-1471.

Frey, B.S., \& Luechinger, S. (2004). Decentralization as a disincentive for terror. European Journal of Political Economy, 20, 509-515.

Hoffman, B. (1998). Inside terrorism. New York: Columbia University Press.

Hubback, A. (1997). Apocalypse when? the global threat of religious cults. Conflict Studies, 300, June.

Ibn, K. (1967). Translated from the Arabic. In: F. Rosenthal (Ed.), The Muqaddimah. An introduction to history (Vol. 3, 2nd ed.). Princeton: Princeton University Press.

Krueger A.B., \& Maleckova, J. (2003). Education, poverty, and terrorism: is there a causal connection? Journal of Economic Perspectives, 17, 119-144.

Morgan, E.S. (1958). The Puritan Dilemma. The story of John Winthrop. New York: Harper Collins.

Peters, R. (1996): Jihad in classical and modern Islam. Princeton: Markus Wiener Publishers.

Qutb, S. (2001). In the shade of the Quran. Vol. IV: Surah 5. Translated and edited by Salahi, Adil and Shamis, Arthur. Markfield (Leicester): The Islamic Foundation.

Rapoport, D.C. (1984). Fear and trembling: terrorism in three religious traditions. American Political Science Review, 78, 658-677.

Sobel, L.A. (Ed.) (1975). Political terrorism. Oxford: Clio Press.

Stayer, J.M. (1976). Anabaptists and the sword. Lawrence (Kansas): Colorado Press. 